\title{
PRESCRIPTIVE POLYGAMY AND COMPLEMENTARY FILIATION AMONG THE IRIGWE OF NIGERIA
}

\author{
WaLter H. Sangree \\ University of Rochester
}

I shall attempt to do three things in this article. First I shall outline very briefly some aspects of the Irigwe polygamous marriage system and note certain difficulties that face Irigwe couples who prefer monogamy. Second I shall illustrate these with a case history and note the ties both to the mother's and the mother's mother's agnatic groups that complement Irigwe patrilineality. Finally I shall analyse how these complementary ties serve to offset contrasting strains placed by the Irigwe system of mandatory polygamy and rclated mystical beliefs both on the individual's agnatic affiliations and on his mystical ties with his 'mother's people'.

The Irigwe are situated about twenty miles west of the towns of Jos and Bukuru on the Jos Plateau in Benue-Plateau State, Nigeria. They are an agricultural tribe of around 17,000 people with their own distinctive language and culture. Traditionally the Irigwe lack a tribal chicf and any formalised political hierarchy as such. Instead the tribe is subdivided into twenty-five patrilineal ritual units or 'sections' (sing. kla, plu. rekla) as they call them. Each section has responsibility for one or another ritual speciality of importance to the entire tribe (Sangree 1970: 33-5). Most of these sections are in turn each subdivided into several exogamous patrilineages (sing. enucie, plu. renucie). Although Irigwe sections are not exogamous in the usual sense of the word the Irigwe system of 'secondary marriage' entails prohibitions similar to section exogamy (Muller \& Sangree 1973: 5I). It is forbidden to take a woman in 'secondary marriage' who is already married to someone of your own section, your mother's section, or your mother's natal compound, and most marriages are between couples with differing section affliation. Thus both ritual interdependence, and an intricate network of cross-cutting affinal ties, including special constraints against co-husband hostility, suppress fighting between the sections and strongly unite them in all inter-tribal matters (Sangree 1972: 1237-8).

There are two basic types of traditional Irigwe marriage (Sangree 1969: 1049s5). One type, arranged by the parents of the couple prior to their adolescence, which involves bride service by the boy's family, I call 'primary marriage.' because ideally it starts a boy's and girl's conjugal career. The other type is arranged by the couple together with her father or marriage guardian, and involves a marriage payment to him rather than bride service. I call this type 'secondary marriage.' Traditionally there is no divorce in Irigwe, and consummating a secondary marriage does not invalidate any of the prior primary or secondary marriages of either marriage partner.

After an Irigwe father has granted permission and received marriage payment Man (N.S.) 9, 44-\$2. 
for two or three of his daughter's sccondary marriages, it is usual for him to select one of his lineage brothers to be his daughter's marriage guardian ( $b E$ bi $n v a)$ to oversee and receive payment for her future secondary marriages. If her father or the marriage guardian he has chosen for her dies, members of a woman's patrilineage select another guardian for her. Thus an Irigwe woman always has a man in her paternal lineage (sometimes her own father, more usually another man of the lineage) who has the right and responsibility to bestow her in secondary marriage upon an indefinite number of new husbands.

Irigwe women may refuse any secondary marriage proposal prior to the marriage payment of 30 to 40 shillings from the suitor to her father or lineage marriage guardian, but she can never contract a marriage without her father's or marriage guardian's consent. Furthermore a father or marriage guardian feels it is within his rights to arrange and have his daughter or ward consummate at least three marriages. A woman may return to any of her spouses at any time, and usually finds herself welcomed back and given a hut and everything she needs for housekeeping. In my Irigwe census sample all women past their teens had at least one secondary as well as a primary marriage. Almost all middle-aged Irigwe men and women have two or more living spouses, and it is not uncommon for them to have half a dozen or so.

A husband in effect competes with his co-husbands (wives' other husbands) both for his wives' sexual services and the children they bear. The question of paternity is settled for each pregnancy by the infant being bestowed, usually without contention, upon whichever husband the woman is resident with when she is pregnant and bears the child.

Elsewhere I have discussed the strains the Irigwe system of secondary marriage places on the domestic arena, and on the psychic well-being of women and children (Sangree 1969: 1055-6). Here it will suffice to note that under the traditional Irigwe secondary marriage system, marrying a plurality of wives is a relatively simple matter, but getting some or even any of these wives to remain resident with you is not at all an easy task. Conversely, from the woman's point of view, three factors severely circumscribe her actual autonomy both in rejecting suitors and in remaining resident permanently, or for long, with the husband she most prefers.

First, a woman can expect 'anger in the heart' of her father or lineage marriage guardian to bring illness to herself or one or more of her children if she persistently refuses to accept the marriage proposals of several successive secondary suitors her father or guardian approves of, or if she procrastinates too long in consummating the marriage with a man to whom she is engaged.

Second, frequently boys, and quite often girls, past the age of threc or four reside in their father's compound and thus remain with their agnatic kin rather than following their mother when she moves to another husband. The recovery of a seriously ill or chronically ill child, however, is believed to depend upon the presence of both its parents (if both are alive); thus a woman not infrequently is obliged to leave one husband to take up residence with another where an unwell child of hers lives; and things can get quite desperate when a woman has two or more ailing children each by a different husband.

Third, regardless of their agnatic affiliation a woman generally keeps her small 
children with her wherever she is living, and a major consideration for a woman in deciding which husband to reside with is where she and her children seem to enjoy the best physical health.

Now I shall turn to the case of an Irigwe couple, both in their middle thirties, who for idiosyncratic reasons that we need not analyse here, preferred to live monogamously with each other, but found it impossible because of various pressures, particularly those exerted by the woman's marriage guardian.

The case of Feci and Dalo

I shall begin when Feci was an adolescent still living in her father's compound and was engaged for primary marriage to a boy from another section. Feci also had two other sweethearts at this time. One was Dalo, a youth of her own section but a different lineage who lived in a nearby compound, and the other was a youth from a third section. Both these sweethearts had made payments to Feci's father and thus were properly engaged to take Feci in secondary marriage sometime after the consummation of her primary marriage. It is a common and fully accepted practice for Irigwe girls to become engaged to one or more secondary marriage suitors even prior to the consummation of their primary marriage. But Feci, who was particularly partial to Dalo, went beyond both the usual and approved practices by having a number of clandestine trysts with Dalo and getting pregnant by him prior to consummating her primary marriage. When Feci's father learned of this he insisted that she immediately take up residence with her primary husband-to-be and consummate their marriage. Thus Feci went to her primary husband, but after only three days she left him and took up residence with Dalo.

Around the sixth month of a girl's first pregnancy a ceremony called sá tēse ('putting outside') which marks her transition from girlhood to adulthood is held for her by her father's lineage at their section shrine centre. The father of the husband with whom the girl is currently residing (and presumably who made her pregnant) escorts her to and attends this ceremony. Feci, however, at her father's insistence, preserved the fiction that her primary husband, rather than Dalo, was the genitor of her unborn child. Thus she returned to her primary husband for this occasion so that his father could escort her to her sá tèse ceremony.

The major social significance of sá tēse to the woman's lineage, and to the lineages of her husbands both present and future is that this ceremonial once and for all transfers paternity rights for all children she might bear from her father's (and her own) patrilineage to those of her husbands. This transference is consummated at sá têse by a ritual involving her baptism with water from her patrilineage's spring which assures that her own soul ( $\bar{o} w u ́)$ will leave the vicinity of her patrilineage's spring and thenceforth remain in or near her regardless of which husband she may be residing with.

A woman's patrilineage surrenders all control over rights in genetricem (Bohannan 1949: 287) at sá tēse; but they retain control over the bestowal of rights in uxorem, and they generally symbolise the fact by encouraging and supporting on that occasion the transference of her marriage guardianship from her father to another man in her patrilineage. In Feci's case her father chose a man to be her new marriage guardian who was from her own lineage but who had spent his youth 
and early adulthood living with his mother's people who were of another section and lineage-by chance the very section and lineage to which Feci's secondary husband Dalo's mother belonged.

Feci stayed with her primary husband after sá tèse and in due time bore a girl there who was considered to be her primary husband's daughter, even though it was generally recognised that Dalo was probably her genitor. Several months later Feci left her primary husband, taking her nursing baby with her, and took up residence again with Dalo. Then Feci's father and her new marriage guardian both told her that she must consummate her marriage with her other secondary suitor just as she had with Dalo, but she refused and just stayed on with Dalo. In time she bore Dalo a son, and a couple of years later a daughter, both of whom were recognised as legally his children. Then the infant daughter became ill and finally died. A diviner said that death resulted from anger in the heart of Feci's father because Feci had refused ever to go and consummate the secondary marriage with the other youth that he had arranged for her years before. So Feci, fearful that her other children might also be afflicted, subsequently went and lived with this other man for a few months, and then returned to Dalo.

During the next several years Feci's marriage guardian consulted with her about several suitors. She didn't want to marry anybody else and refused them. Finally fearing for the welfare of her surviving children if she continued to defy her marriage guardian as she had her father, she consented to marry the suitor that he most persistently put forth, but she left all details, such as checking on possible violation of marriage prohibitions, up to her marriage guardian. The new engagement was quickly made binding by the customary payment to her marriage guardian; but Feci let months, and finally years, pass without ever going to this new francé and consummating their marriage. Then an incident occurred that induced her to run in near panic to this new husband.

In order to explain the significance of this incident I must now digress a moment from the story of Feci and Dalo to outline the importance and nature of the ow $w u$ or soul, and note the special link it forges with the 'mother's people' (né tékwē). The presence or proximity of every man or woman's soul, which is believed to come to one via the mother's patrilineage, is considered vital to a person's wellbeing and continued good health. Thus as soon as a woman gives birth her husband or one of his male lineage mates runs to her paternal lineage's spring and fetches back a small gourdful of water and two pebbles. He baptises the mother and newborn child with this water and throws the pebbles into the mother's water pot $\mathrm{kcpt}$ in the back of her hut. These rites are said to assure that the infant will receive its soul from his mother's people and that the soul will thenceforth either lodge in the baby's person or nearby in the waterpot or at the patrilineage's spring. Normally no further ceremonies are necessary to assure the presence or proximity of a male child's soul since he will usually reside patrilocally for his entire life. But a girl frequently spends much of her childhood with her mother when the latter is residing with other husbands; also a female resides virilocally after marriage. Thus when a girl first shows signs of puberty a ceremonial (called $t i$ yince) is held for her which includes her being conducted to her patrilineage's spring to draw water and carry it back to her section's shrine house. Her own mother presides at this ceremonial which among other things is seen as reasserting and reassuring the 
transference of the proper abode of a girls's soul from her mother's lineage to the girl's lineage. We have seen that a few years later at the sá têse ceremonial held when the girl is first pregnant her soul is induced to leave the vicinity of her father's spring and accompany her wherever she resides thereafter. It is believed especially important to assure a safe delivery that a woman's soul be present when she gives birth.

The 'mother's people' (né tékwē), from whom it is believed every person receives his or her soul, have a special place in every Irigwe's life. As we have seen, anger in the heart of the mother's father can bring illness and death to her children even though the anger is provoked by the mother's rather than the children's own actions. A dominant theme in Irigwe world view is that life-giving forces also have their lethal aspects (Sangree I971: 64-5, 69-70), and the soul-mediated connexion between the 'mother's people' and the sister's children is seen as no exception to this. Normally 'mother's people' are very solicitous about the welfare of their sisters' (and daughters') children, and they are the latter's first refuge in times of difficulty with their own lineage. Also a man can always help himself to as much grain from his 'mother's people's' granaries as he or his wife can carry in one load; in contrast a man has no rights to take freely from granaries (other than his own) in his own lineage.

Now I shall return to the incident that induced Feci to run in panic to her new husband. One day Dalo sent Feci to take a basket of grain from one of his 'mother's people' where she had never been before. When she arrived at his compound she was horrified to see that the granary owner was none other than the man to whom she had been betrothed by her marriage guardian. Thus she learned she had inadvertently been engaged to a 'mother's brother' (ne tékwe or $n y \bar{E}$ ) of Daloand it is strictly against Irigwe custom for mothers' brothers' and sisters' children ever to take each other's wives in secondary marriage. Feci knew that once Dalo learned of the engagement he would immediately let his relationship to her new fiancé be known. The engagement would then be called off, and her marriage guardian as well as looking like a bungler, would be obliged to return the marriage fee. Feci became almost panic-stricken because she feared that after her years of recalcitrance about marrying anyone new her marriage guardian would be so vexed that the anger in his heart would rise against her and cause one or more of her surviving children to sicken and die. Thus she returned to Dalo without taking the grain, saying she was not well and would get it another day; and she resolved to leave him that very night and go and consummate the marriage with this new husband before anyone discovered the relationship between him and Dalo.

The following morning when Dalo discovered where Feci had gone he stood in the centre of his compound and roarcd death and destruction against his mother's brother who had taken his wife, and ranted that he would never take Feci back. As elders of his lineage and section came to see what the noise was about Dalo was stricken with a terrible pain in his ribs. The elders ruled that this pain came because he had yelled against his mother's brother who had in all innocence married the wife of his sister's son. They assured him that no one-not Feci, not her new husband, nor her marriage guardian-had been aware of the mistake when arranging the marriage, and then counselled him to calm down, call Feci back, and not make 
things worse. One of Dalo's lineage mates fetched Feci back, and by the time she returned to Dalo that afternoon his chest pain has subsided.

Under most circumstances the marriage between Feci and Dalo's mother's brother would next have followed a course dictated primarily by Dalo's feelingsparticularly by his desire to avoid stirring up anger in the heart of this mother's brother that might bring him sickness; but an additional complicating factor came to light-namely that this new husband of Feci's stood in the relation of mother's brother ( $n \bar{e} t e ́ k w \bar{e}$ or $n \gamma \bar{E}$ ) not only to Dalo, but also to Feci's marriage guardian. Thus Feci's marriage guardian, because he feared angering this new husband of his ward and thus endangering his own health, kept urging her to return to her new husband. She refused until she realised she was pregnant again; then, fearing particularly for the health of her unborn child, she went to her new husband for a - couple more nights after which she returned to Dalo's to live where in due course she gave birth to a baby girl. The infant thrived for around six months and then quite suddenly became sick. A diviner said that anger in the hearts of both Feci's father and her marriage guardian was the cause. The baby ailed for many weeks; and one day Feci's father and marriage guardian came to her and said, 'We challenge you to show who's boss!' Feci's father then pointed out that her marriage guardian had to respect the feelings of her new husband who was his mother's brother $(n \bar{e} t e \dot{e} k w \bar{e}$ or $n y \bar{E}$ ) and thus she would have to go back to her new husband for the sake of her child's health.

Feci talked the matter over with Dalo, and he vehemently objected, saying she had spent the required minimum three nights with the new husband, and that no marriage guardian could rightfully demand more. Dalo and Feci, it will be recalled, although from differing patrilineages (renucie), belonged to the same section $(k l a)$. Dalo asserted that Feci's father and marriage guardian, since they were elders of his own section, had no right to urge a course for his wife that would deprive him, a son of their own section, of a wife that he cherished. But the elders of Dalo's own lineage disagreed with him and they together with elders of other lineages of this section including Feci's father and marriage guardian, counselled him to accept Feci's going back to her new husband again in order to maintain harmony between the patrilineages of their section. People on all sides urged Dalo simply to busy himself and find recompense in the usual Irigwe way by seeking new secondary marriage unions with women married into other sections of the tribe. But Dalo's feelings of being wronged simply could not be assuaged. In such conflicts with one's own section seniors a man usually turns to his 'mother's people' (né tékwē) for support and refuge if necessary; but in this instance Dalo could not do this because Feci's new husband belonged to Dalo's mother's sectionindeed to her very patrilineage; consequently Dalo's 'mother's people' (né tékwēe) all felt bound to support the new marriage of one of their section brothers more than the wishes of a non-resident sister's son. Dalo, feeling abandoned by both his own and his 'mother's people', resolved to ignore them all and counselled Feci not to go to her new husband because that is what he himself wanted.

About a week later Dalo returned from a day of farming and was greeted at his hut by Feci who handed him the still warm corpse of their baby girl. Overcome with grief and fearing for the health of her surviving children Feci took off for her new husband even before the customary mourning period was over. Dalo buried 
his anger and grief by immediately leaving the tribe and finding work as a carpenter's helper in a distant urban centre. Four months later, fceling more in control of himself, he returned home. At first he did not call Feci back, but instead followed the advice of his section peers and clders and took another wife in secondary marriage. Hc found a tough spccimen (in no way related to him) who had been living with an Irigwe man of another section; and after a few wecks she left Dalo to take up with a Muslim man in a nearby village. Then he called Feci who promptly returned to him. She was several months pregnant.

By the final wecks of my fieldwork in Irigwe this new baby, also a girl, was about eight months old. Feci was domiciled with Dalo, but she frequently took the baby over to visit her new husband-i.c., Dalo's mother's brother (nẽ tékwē or $n \gamma \bar{E}$ ) - who was recognised as the infant's legal father (Sangrce 1969: Io52-3); and Dalo felt he finally had been able to achieve a reasonable co-husband avoidance type relationship (Sangree 1972: 1237-8) with this man. Feci and Dalo each assured me that if this new baby or any of their children became sick and it was ascertained by a diviner that anger in the heart of Feci's father or marriage guardian was the cause, they would both shun these two men for the rest of their lives. Rarely did I hear of a grown Irigwe man's illness being attributed to anger in the heart of his father or any other living member of his own patrilineage or section, but it is commonly held to be dangerous to enrage an clder of one's own section because the elder might die still angry, and nothing is considered more fearsome than the vengeful ghost $(\dot{u} r \bar{u})$ of an eldcr, particularly an agnatic elder. Thus I protested that it might later be dangerous for them and their children to have the vengeful ghosts of the deceased section elders they had shunned troubling them and their children. Dalo and Feci assured me, however, that in such an cventuality Dalo would again have the full support of his 'mother's people' since the health of one of their own section's children would now be involved, and Feci, of course could turn to her own 'mother's people' for support. Then they told me something I had not known before, namely that the kin group believed in Irigwe best able to call off a vengeful ghost is not one's own patrilineage or section elders, not one's 'mother's people' (né tékwē), but one's 'mother's mother's people' (né tékwē ná hwié).

Irigwe is a strongly patrilineal society in both a politico-jural and a ritual sense; and in a manner typical of unilineal descent systems, as Fortcs and others have so ably demonstrated (Fortes 1969: 97-100), complementary functions in these domains are performed by the parental lineage of the descent group to which the individual does not belong, i.e., the 'mother's people' (né tékwē) in Irigwe. 'Mother's pcople', and the privileges this avuncular type of relationship bestows in Irigwe, such as the right to take food from their granaries, and expcctations of hospitality and refuge, may bc in some contexts extended to any and all members of one's mother's natal section; but in the casc of offspring of a scction-endogamous union, the usual 'mother's pcople'-sister's child relationship is confined to the mother's patrilineage, and particularly those members living in the mother's natal compound (ari tékwè). A person has the same type of privileged relationship with his or her 'mother's mother's pcople' (né tékwē ná hwie), but it is extended only to the people of the mother's mother's natal compound (ari tékwè nà hwíe); and when a sister's daughter's child dies special mortuary prestations which may be 
made by the surviving heirs terminate this relationship once and for all for them and their descendants.

We have seen that in Irigwe for every individual the 'mother's people' are not only a possible political asylum, jural backup, and source of economic largesse, but also that this group is seen as the bestower of the soul (owí) believed crucial to a person's health; a dependent child's relationship to his or her soul can be disturbed mystically to the child's detriment by the mother's relationship with her agnatic lineage, particularly through conflict she may have with her father or marriage guardians over her secondary marriages and resulting anger in their

- hearts against her. Consequently the relationship with the 'mother's people' is in a very real sense frequently compromised by the mother in a person's infancy or early childhood. In any case, the process of soul bestowal forges a life-long mystical

- dependency for an individual upon the 'mother's people', and if good relationships are ruptured with the 'mother's people', as when Dalo yelled against his mother's brother/co-husband, ill health for the sister's child is expected to ensue. The 'mother's mother's people' (né tékwē ná hwié), however, are not involved in one's soul bestowal; thus it is they, the nearest kin group not implicated in one's own or one's children's illnesses, who become the ultimate sanctuary and source of support in times of conflict with one's agnates and/or 'mother's people'.

Elsewhere I have discussed the fundamental importance of the network of cohusband bonds mediated by secondary marriage to inter-section peace keeping and thus to Irigwe tribal solidarity (Sangree I972: I 237-8). Irigwe assert that both men and women of their tribe usually prefer to have many spouses; but they also recognise that daughters not infrequently displease their marriage guardians by disagreeing with them about whom and when they should marry. I never heard any Irigwe criticise Feci's or other women's reluctance to honour secondary marriage alliances as an impediment to tribal solidarity; instead such recalcitrance was viewed simply as a breach of filial duty with possible serious consequences for the women's offspring.

The case of Dalo and Feci is strongly aberrant in one sense, namely I know of no other case where an Irigwe man has found himself with one of his own mother's brothers for a co-husband; this forbidden alliance, given Feci's intransigent desire not to leave Dalo, was consummated only because of the strength of the Irigwe mystical sanctions compelling a woman to fulfil the desires of her father or marriage guardian as regards her secondary marriages. In no sense do we have a double descent system operative in Irigwe; but in practice the complementary mystical

- powers of the mother's agnatic descent groups are so great, and through marriage guardianship so encumbered by the ongoing ties of the mother with that group, that an alternative to that group must be available to assure the individual's well- being. As we have seen the 'mother's mother's people' known literally as 'mother's people number two' (né tékwè ná hwie) thus assume special importance as the kin group to which an individual can always turn without memories of prior maternal intransigence chilling the reception.

\section{NOTES}

This article is a revision and expansion of a paper read at the Northeastern Anthropological Association Annual Meetings, Buffalo, N.Y., April 1972. I an indebted to Jean-Claude Muller 
for his helpful criticisuls. The field research in Irigwe, Benue-Plateau State, Nigeria, on which this article is based was conducted by the author between August I 963 and July I965, and was financed by a grant from the National Science Foundation.

\section{REIEREN CES}

Bohannan, Laura I949. Dahoinean marriage: a revaluation. Africa I9, 273-87.

Fortes, Meyer 1969. Kinship and the social order. Chicago: Aldine.

Muller, Jean-Claude \& Walter H. Sangree I973. Irigwe and Rukuba marriage: a comparison. Canad. J. Afr. Stud. 7, 27-57.

Sangree, Walter H. I969. Going home to mother: traditional marriage among the Irigwe of Benue-Plateau State, Nigeria. Am. Anthrop. 71, 1046-57.

1970. Tribal ritual, leadership and the mortality rate in Irigwe, Northern Nigeria. SWest. J. Anthrop. 26, 32-9.

I97I. La Gémellité et le principc d'ambiguité: commandement, sorcellerie et maladie chez les Irigwe (Nigeria). Homme 11 : 3, 64-70.

I972. Secondary marriage and tribal solidarity in Irigwe, Nigeria. Am. Anthrop. 74, I234-43. 